\title{
THYROXINE-BINDING BY SERA OF PREGNANT WOMEN, NEW- BORN INFANTS, AND WOMEN WITH SPONTANEOUS
} ABORTION ${ }^{1}$

\author{
By J. THOMAS DOWLING, ${ }^{2}$ NORBERT FREINKEL, AND SIDNEY H. INGBAR \\ (From the Thorndike Memorial Laboratory and Second and Fourth (Harvard) Medical \\ Services, Boston City Hospital, and the Department of Medicine, Harvard Medical \\ School, Boston, Massachusetts, and the Howard Hughes Medical Institute)
}

(Submitted for publication May 10, 1956; accepted August 2, 1956)

Among the many physiological alterations which may occur during pregnancy are thyromegaly (1), augmented thyroidal avidity for iodine $(2,3)$, and increase in the concentration of circulating thyroid hormone $(4,5)$. This triad of anatomical and functional alterations is ordinarily considered to be diagnostic of thyrotoxicosis. Paradoxically, however, these findings are neither accompanied by symptomatic stigmata of hyperthyroidism, nor are they associated, during the first half of pregnancy, with increase in the basal metabolic rate. Although the basal metabolic rate increases during the latter half of pregnancy, this change has been ascribed by some to fetal needs, and not to alterations in maternal energy requirements (6). The origins and consequences of this unique functional dissociation are unknown.

Recently there has been considerable interest in the physiological role and physicochemical properties of the specific thyroxine-binding protein or proteins of plasma (TBP). Although the physiological role of TBP has not been elucidated, demonstration of this alpha globulin moiety in 1952 provided another parameter of thyroidal economy which is susceptible to measurement (7-11). Even earlier it had been suggested that the increased SPI of pregnancy might result from an alteration in the manner in which thyroxine in plasma is protein-bound $(12,13)$. Therefore, it appeared possible that study of the thyroxine-

1 This investigation was supported in part by research grant No. A-267 from the National Institute of Arthritis and Metabolic Diseases of the National Institutes of Health, Public Health Service, and in part by the Medical Research and Development Board, Office of The Surgeon General, Department of the Army, under Contract No. DA-49-007-MD-412.

${ }^{2}$ Fellow in Cancer Research of the American Cancer Society. binding capacity of TBP in serum might provide a clue to the origin of the peculiar alterations in the metabolism of iodine which occur during pregnancy. This possibility seemed particularly attractive in view of repeatedly demonstrated alterations, during pregnancy, in the electrophoretic composition of the proteins of plasma (14-16).

For these reasons the present study of the interaction of thyroxine with the proteins of sera obtained from pregnant women was undertaken. A marked increase has been found in either the concentration of TBP, or in its avidity for thyroxine. It is suggested that this increase may be directly related to the alterations in the metabolism of iodine which occur in the pregnant woman. $\dot{A}$ brief preliminary report of this finding has been published elsewhere (17).

\section{MATERIALS AND METHODS}

Thirty $\mathrm{ml}$. of venous blood were obtained without stasis from 27 non-pregnant women of childbearing age, without regard to the phase of the menstrual cycle, from 22 pregnant women divided among the three trimesters of uncomplicated pregnancy, and from 6 pregnant women with a diagnosis of threatened or inevitable abortion. In an additional 8 instances, maternal and umbilical cord bloods were obtained at the time of normal, full-term delivery. Other samples studied included venous blood drawn serially from 3 patients at delivery and during the first, third, and fifth post-partum weeks, and blood from 2 pregnant women at the estimated twenty-first postovulatory day. Serum was obtained following clot retraction. Aliquots of serum were immediately analyzed for albumin and for total protein. The remaining serum was frozen until used for studies of thyroxinebinding.

Concentrations of albumin in the sera were determined, in duplicate, by the colorimetric, dye-adsorption method of Rutstein, Ingenito, and Reynolds (18). Standard curves of optical density were obtained, using a Coleman Junior spectrophotometer. The following preparations of albumin were intercompared in order to obtain albu- 
min reference standards: Fraction $\mathrm{V}$ of Cohn method 6 (19), mercaptalbumin (20), ${ }^{3}$ and two lots of 25 per cent ARC human serum albumin. Standards containing mercaptalbumin and Fraction V were prepared gravimetrically; standards of ARC human albumin were prepared by dilution. Close agreement was noted between colorimetrically determined values and the nitrogen content of the mercaptalbumin standard, as determined by Kjeldahl analysis. The reliability of using 25 per cent ARC human serum albumin as a standard for the method was thereby verified. A new standard curve was obtained for each set of determinations.

Concentrations of total protein were determined, in duplicate, by the biuret method (21), standardized by Kjeldahl determinations of nitrogen in the reference solutions of human albumin.

Analyses for serum precipitable iodine (SPI) were performed by the alkaline ash method of Barker, Humphrey, and Soley $(22,23) .^{4}$

In order to assess the proportionate distribution of thyroxine between TBP and albumin at varying concentrations of thyroxine, sera to be compared in a single experiment were treated concurrently in the following manner. Into the first of $413 \times 100 \mathrm{~mm}$. test tubes were added $5.0 \mathrm{ml}$. of serum and $0.100 \mathrm{ml}$. of an approximately $5.0 \mu \mathrm{g}$. per $\mathrm{ml}$. solution of newly received, chromatographically pure radiothyroxine. ${ }^{5}$ Two $\mathrm{ml}$. of this mixture was transferred to the fourth tube. Into the fourth tube was then added $0.100 \mathrm{ml}$. of a $3.0 \pm 0.2 \mathrm{mg}$. per cent solution of stable thyroxine, ${ }^{6}$ made up in 1.0 per cent human albumin. Solutions of stable thyroxine were prepared in 1.0 per cent albumin in order to minimize adsorption of thyroxine to glassware. In order to compensate for the albumin added to the fourth tube, 0.150 $\mathrm{ml}$. of a 1.0 per cent solution of human albumin containing no thyroxine was added to the $3 \mathrm{ml}$. of serum remaining in the first tube. At this point, serum in the fourth tube contained approximately $150 \mu \mathrm{g}$. per cent of added stable thyroxine; serum in the first tube contained none. Serum in both the tubes contained approximately $50 \mathrm{mg}$. per cent of added human albumin. One-ml. aliquots of serum from the first and fourth tubes were then mixed in the third tube. Finally, $1.0-\mathrm{ml}$. aliquots of serum from the first and third tubes were mixed in the second tube. Thus, concentrations of added stable thyroxine of approximately 37.5 and $75.0 \mu \mathrm{g}$. per cent were achieved in the second and third tubes, respectively. Approximately $10 \mu \mathrm{g}$. per cent of additional thyroxine were contributed to the serum in each tube by the radiothyroxine added.

${ }^{3}$ Mercaptalbumin dialyzed against cysteine was kindly supplied by Dr. Margaret J. Hunter, Department of Biophysical Chemistry, Harvard Medical School.

4 Performed by Bio-Science Láboratories, $2231 \mathrm{~S}$. Carmelina Avenue, Los Angeles, California.

5 Obtained from Abbott Laboratories, Oak Ridge, Tennessee.

${ }^{6}$ Kindly supplied by Dr. A. E. Hemming, Smith, Kline \& French Laboratories, Philadelphia, Pennsylvania.
In most experiments, the concentrations of SPI achieved were chemically determined in two sets of sera. SPI values, obtained by dilution of enriched sera were not only higher than values predicted on the basis of gravimetric addition, but also were not consistent from experiment to experiment. However, the distribution of thyroxine between albumin and TBP in the same control sera showed only occasional variation when electrophoresed in different experiments. The latter finding suggested that concentrations of thyroxine achieved in the various experiments were, in fact, usually quite similar. It was thus decided to report, in the accompanying tables and figures, concentrations of added thyroxine based on gravimetric addition. However, in order to eliminate the effects of variations in preparative techniques as well as in the adsorption of thyroxine to glassware (24), each experiment was designed so that the partition of thyroxine in experimental sera could be directly compared with that observed in concurrently assayed controls.

Additional experiments were performed in which each sample of serum from the pregnant subjects was gravimetrically enriched with mercaptalbumin in amounts sufficient to achieve albumin concentrations equal to the highest concentrations among control sera. The partition of thyroxine was then assessed by the techniques described below. The binding affinity for thyroxine of the mercaptalbumin added was assayed by electrophoresis of this protein in solutions containing the four concentrations of thyroxine used in studying thyroxine-binding in serum.

Since all of the above experiments entailed the addition of sufficient radiothyroxine to increase the concentration of endogenous thyroid hormone by at least 100 per cent, further studies were performed with truly tracer amounts of the radioactive material. Sera from pregnant females and non-pregnant controls were diluted tenfold with saline. To $0.9-\mathrm{ml}$. aliquots of the diluted sera were added $0.1 \mathrm{ml}$. of a $10 \mathrm{gm}$. per cent albumin solution which contained a small amount of endogenous protein-bound iodine as well as $0.14 \mu \mathrm{g}$. per $\mathrm{ml}$. and 4.3 $\mu c$. per $\mathrm{ml}$. of added $\mathrm{I}^{131}$-thyroxine. The resultant mixtures, in which it was hoped to approximate the concentrations of total protein, albumin, and PBI of the extracellular fluid, were then electrophoresed on paper.

Using apparatus and techniques described elsewhere (24), 32 individual electrophoretograms (samples from 8 patients) were obtained in duplicate daily on consecutive days until all samples had been electrophoresed. Earlier, it had been shown that no difference in the partition of thyroxine resulted when aliquots of the same sample of thyroxine-enriched serum were electrophoresed at intervals of 4 days. One filter paper sheet of a duplicate pair was subdivided into its 8 component electrophoretograms. These individual electrophoretograms were then scanned for radioactivity in an automatic strip scanner utilizing a gas-flow counter. The other sheet was radio-autographed on no-screen $x$-ray film and subsequently stained for proteins by the method of Durrum (25). In certain instances, the components of serum in 
TABLE I

Distribution of thyroxine between TBP and albumin during filter-paper electrophoresis of sera from pregnant women

\begin{tabular}{|c|c|c|c|c|c|c|c|c|c|c|c|}
\hline \multirow[b]{3}{*}{ Subject } & \multicolumn{8}{|c|}{ Thyroxine added $(\mu \mathrm{g} . / 100 \mathrm{ml} .)^{*}$} & \multirow{3}{*}{$\begin{array}{l}\underset{\text { PBI }}{\text { Serum }} \\
(\mu \mathrm{g} . / 100 \mathrm{ml} .)\end{array}$} & \multirow{3}{*}{$\begin{array}{c}\text { Serum } \\
\text { total } \\
\text { protein } \\
(\mathrm{gm} . / 100 \mathrm{ml} .)\end{array}$} & \multirow{3}{*}{$\underset{\substack{\text { Serum } \\
\text { albumin } \\
(\mathrm{gm.} / 100 \mathrm{ml} .)}}{.}$} \\
\hline & \multicolumn{2}{|c|}{10} & \multicolumn{2}{|c|}{48} & \multicolumn{2}{|c|}{85} & \multicolumn{2}{|c|}{160} & & & \\
\hline & TBP† & A & TBP & A & TBP & A & TBP & A & & & \\
\hline \multicolumn{12}{|c|}{ Non-pre 6 nant Women } \\
\hline $\begin{array}{l}1 \\
2 \\
3 \\
4 \\
5 \\
6 \\
7 \\
8 \\
9\end{array}$ & $\begin{array}{l}81.4 \\
85.6 \\
81.7 \\
80.5 \\
80.2 \\
77.6 \\
82.4 \\
80.1 \\
74.1\end{array}$ & $\begin{array}{r}9.7 \\
10.5 \\
10.9 \\
14.0 \\
13.8 \\
18.4 \\
13.1 \\
16.3 \\
21.6\end{array}$ & $\begin{array}{l}55.0 \\
54.2 \\
51.8 \\
53.3 \\
49.2 \\
43.1 \\
53.9 \\
52.3 \\
39.0\end{array}$ & $\begin{array}{l}36.1 \\
37.4 \\
40.1 \\
41.8 \\
45.2 \\
44.9 \\
39.6 \\
41.8 \\
52.4\end{array}$ & $\begin{array}{l}47.6 \\
42.5 \\
42.3 \\
41.5 \\
34.9 \\
32.9 \\
41.1 \\
38.1 \\
25.6\end{array}$ & $\begin{array}{l}46.3 \\
50.6 \\
50.5 \\
53.1 \\
57.1 \\
58.1 \\
51.3 \\
57.0 \\
66.4\end{array}$ & $\begin{array}{l}37.4 \\
34.1 \\
33.0 \\
38.3 \\
22.1 \\
22.0 \\
28.1 \\
25.2 \\
19.9\end{array}$ & $\begin{array}{l}53.4 \\
56.7 \\
58.4 \\
55.4 \\
71.5 \\
69.6 \\
64.3 \\
64.6 \\
71.6\end{array}$ & $\begin{array}{l}4.7 \\
5.0 \\
5.1 \\
4.9 \\
5.9 \\
6.0 \\
5.4 \\
5.2 \\
5.2\end{array}$ & $\begin{array}{l}6.4 \\
6.9 \\
7.0 \\
7.2 \\
6.3 \\
6.4 \\
7.2 \\
7.1 \\
7.1\end{array}$ & $\begin{array}{l}3.9 \\
4.0 \\
4.6 \\
4.5 \\
3.9 \\
4.0 \\
4.5 \\
4.0 \\
4.1\end{array}$ \\
\hline $\begin{array}{l}\text { Mean } \\
\text { Std. dev. }\end{array}$ & $\begin{array}{r}80.4 \\
3.2\end{array}$ & $\begin{array}{r}14.6 \\
2.9\end{array}$ & $\begin{array}{r}50.2 \\
5.5\end{array}$ & $\begin{array}{r}42.1 \\
4.9\end{array}$ & $\begin{array}{r}38.5 \\
6.5\end{array}$ & $\begin{array}{r}54.5 \\
5.9\end{array}$ & $\begin{array}{r}28.9 \\
7.0\end{array}$ & $\begin{array}{r}62.8 \\
7.1\end{array}$ & $\begin{array}{l}5.3 \\
0.4\end{array}$ & $\begin{array}{l}6.8 \\
0.4\end{array}$ & $\begin{array}{l}4.1 \\
0.3\end{array}$ \\
\hline \multicolumn{12}{|c|}{ First Trimester ( 6 to 13 weeks, inclusive) } \\
\hline $\begin{array}{l}1 \\
2 \\
3 \\
4 \\
5 \\
6\end{array}$ & $\begin{array}{l}90.3 \\
89.2 \\
90.9 \\
91.2 \\
91.6 \\
90.0\end{array}$ & $\begin{array}{l}6.5 \\
5.0 \\
5.4 \\
5.3 \\
5.5 \\
6.5\end{array}$ & $\begin{array}{l}79.5 \\
82.5 \\
78.0 \\
87.8 \\
81.3 \\
77.4\end{array}$ & $\begin{array}{r}15.6 \\
11.2 \\
15.7 \\
8.9 \\
15.1 \\
17.8\end{array}$ & $\begin{array}{l}64.3 \\
63.9 \\
65.0 \\
68.6 \\
65.0 \\
63.0\end{array}$ & $\begin{array}{l}28.6 \\
35.9 \\
30.1 \\
26.2 \\
30.0 \\
30.6\end{array}$ & $\begin{array}{l}43.0 \\
55.6 \\
56.0 \\
47.5 \\
41.5 \\
43.0\end{array}$ & $\begin{array}{l}49.7 \\
38.8 \\
38.6 \\
44.5 \\
48.0 \\
47.0\end{array}$ & $\begin{array}{r}7.8 \\
7.3 \\
10.0 \\
6.9 \\
6.5 \\
10.0\end{array}$ & $\begin{array}{l}5.8 \\
6.9 \\
6.5 \\
6.7 \\
6.5 \\
6.0\end{array}$ & $\begin{array}{l}3.7 \\
3.2 \\
3.6 \\
3.3 \\
3.8 \\
3.6\end{array}$ \\
\hline $\begin{array}{l}\text { Mean } \\
\text { Std. dev. }\end{array}$ & $\begin{array}{r}90.5 \\
0.9\end{array}$ & $\begin{array}{l}5.7 \\
0.6\end{array}$ & $\begin{array}{r}81.1 \\
3.8\end{array}$ & $\begin{array}{r}14.0 \\
3.3\end{array}$ & $\begin{array}{r}65.0 \\
1.9\end{array}$ & $\begin{array}{r}30.2 \\
3.2\end{array}$ & $\begin{array}{r}47.8 \\
6.5\end{array}$ & $\begin{array}{r}44.4 \\
4.7\end{array}$ & $\begin{array}{l}8.1 \\
1.6\end{array}$ & $\begin{array}{l}6.4 \\
0.4\end{array}$ & $\begin{array}{l}3.5 \\
0.2\end{array}$ \\
\hline \multicolumn{12}{|c|}{ Second Trimester (14 to 27 weeks, inclusive) } \\
\hline $\begin{array}{r}7 \\
8 \\
9 \\
10 \\
11 \\
12 \\
13 \\
14\end{array}$ & $\begin{array}{l}93.4 \\
93.9 \\
92.7 \\
93.3 \\
91.3 \\
93.6 \\
95.0 \\
91.3\end{array}$ & $\begin{array}{l}3.6 \\
3.5 \\
4.9 \\
4.0 \\
4.8 \\
4.9 \\
3.9 \\
4.5\end{array}$ & $\begin{array}{l}77.8 \\
87.5 \\
75.4 \\
83.9 \\
79.4 \\
82.8 \\
84.4 \\
76.5\end{array}$ & $\begin{array}{r}13.0 \\
8.5 \\
17.1 \\
10.2 \\
14.9 \\
12.1 \\
9.8 \\
17.3\end{array}$ & $\begin{array}{l}62.0 \\
69.7 \\
62.2 \\
69.1 \\
61.6 \\
68.2 \\
67.0 \\
66.4\end{array}$ & $\begin{array}{l}35.0 \\
21.8 \\
30.2 \\
23.6 \\
30.9 \\
23.9 \\
23.9 \\
32.9\end{array}$ & $\begin{array}{l}47.5 \\
57.2 \\
45.7 \\
57.7 \\
45.9 \\
50.5 \\
48.3 \\
40.2\end{array}$ & $\begin{array}{l}42.6 \\
34.2 \\
47.9 \\
36.1 \\
45.8 \\
40.1 \\
38.4 \\
48.6\end{array}$ & $\begin{array}{l}8.5 \\
8.9 \\
6.1 \\
6.9 \\
4.9 \\
8.8 \\
7.0 \\
6.5\end{array}$ & $\begin{array}{l}6.3 \\
6.7 \\
6.3 \\
6.0 \\
6.5 \\
6.6 \\
6.3 \\
6.6\end{array}$ & $\begin{array}{l}4.0 \\
3.1 \\
3.5 \\
3.7 \\
3.7 \\
3.5 \\
3.0 \\
3.6\end{array}$ \\
\hline $\begin{array}{l}\text { Mean } \\
\text { Std. dev. }\end{array}$ & $\begin{array}{r}93.1 \\
1.3\end{array}$ & $\begin{array}{l}4.3 \\
0.6\end{array}$ & $\begin{array}{r}81.9 \\
4.2\end{array}$ & $\begin{array}{r}12.9 \\
3.3\end{array}$ & $\begin{array}{r}65.8 \\
3.3\end{array}$ & $\begin{array}{r}27.8 \\
5.0\end{array}$ & $\begin{array}{r}49.1 \\
5.9\end{array}$ & $\begin{array}{r}41.6 \\
5.5\end{array}$ & $\begin{array}{l}7.2 \\
1.3\end{array}$ & $\begin{array}{l}6.4 \\
0.2\end{array}$ & $\begin{array}{l}3.5 \\
0.3\end{array}$ \\
\hline \multicolumn{12}{|c|}{ Third Trimester ( 28 to 40 weeks, inclusive) } \\
\hline $\begin{array}{l}15 \\
16 \\
17 \\
18 \\
19 \\
20 \\
21 \\
22\end{array}$ & $\begin{array}{l}93.7 \\
95.3 \\
92.4 \\
87.4 \\
86.5 \\
87.4 \\
92.8 \\
89.5 \\
\end{array}$ & $\begin{array}{l}3.5 \\
4.0 \\
5.2 \\
3.4 \\
5.0 \\
7.5 \\
4.6 \\
6.4\end{array}$ & $\begin{array}{l}84.2 \\
89.7 \\
83.2 \\
86.4 \\
81.6 \\
82.3 \\
82.2 \\
70.3\end{array}$ & $\begin{array}{r}12.3 \\
7.5 \\
9.8 \\
6.4 \\
13.8 \\
15.3 \\
15.4 \\
21.9\end{array}$ & $\begin{array}{l}65.6 \\
72.7 \\
73.3 \\
71.7 \\
63.0 \\
61.7 \\
64.6 \\
54.9\end{array}$ & $\begin{array}{l}28.8 \\
21.2 \\
21.0 \\
21.3 \\
29.2 \\
28.2 \\
28.6 \\
46.7\end{array}$ & $\begin{array}{l}48.3 \\
52.7 \\
61.0 \\
52.0 \\
48.6 \\
43.0 \\
45.7 \\
39.6\end{array}$ & $\begin{array}{l}44.9 \\
39.0 \\
32.8 \\
39.8 \\
42.9 \\
46.6 \\
46.7 \\
50.3\end{array}$ & $\begin{array}{r}8.8 \\
10.6 \\
9.5 \\
7.1 \\
8.2 \\
8.7 \\
8.7 \\
7.0\end{array}$ & $\begin{array}{l}6.3 \\
6.5 \\
6.3 \\
6.4 \\
6.3 \\
6.9 \\
5.5 \\
6.2\end{array}$ & $\begin{array}{l}3.6 \\
3.7 \\
3.7 \\
2.8 \\
3.1 \\
3.3 \\
2.8 \\
3.5\end{array}$ \\
\hline $\begin{array}{l}\text { Mean } \\
\text { Std. dev. }\end{array}$ & $\begin{array}{r}90.6 \\
3.4 \\
\end{array}$ & $\begin{array}{l}4.9 \\
1.4\end{array}$ & $\begin{array}{r}82.5 \\
5.6\end{array}$ & $\begin{array}{r}12.5 \\
5.0\end{array}$ & $\begin{array}{r}65.9 \\
6.4\end{array}$ & $\begin{array}{r}26.9 \\
5.4\end{array}$ & $\begin{array}{r}48.9 \\
6.6\end{array}$ & $\begin{array}{r}42.9 \\
5.5\end{array}$ & $\begin{array}{l}8.6 \\
1.2\end{array}$ & $\begin{array}{l}6.3 \\
0.4\end{array}$ & $\begin{array}{l}3.3 \\
0.4\end{array}$ \\
\hline \multicolumn{12}{|c|}{ Entire Pregnant Group } \\
\hline $\begin{array}{l}\text { Mean } \\
\text { Std. dev. }\end{array}$ & $\begin{array}{r}91.5 \\
2.4\end{array}$ & $\begin{array}{l}4.9 \\
1.2\end{array}$ & $\begin{array}{r}81.8 \\
4.5\end{array}$ & $\begin{array}{r}13.3 \\
3.5\end{array}$ & $\begin{array}{r}65.6 \\
4.2\end{array}$ & $\begin{array}{r}27.7 \\
4.5\end{array}$ & $\begin{array}{r}48.7 \\
6.0\end{array}$ & $\begin{array}{r}42.8 \\
5.1\end{array}$ & $\begin{array}{l}7.9 \\
1.4\end{array}$ & $\begin{array}{l}6.4 \\
0.3\end{array}$ & $\begin{array}{l}3.4 \\
0.3\end{array}$ \\
\hline
\end{tabular}

* Based on original gravimetric addition.

$\dagger$ Per cent of total radioactivity associated with the thyroxine-binding protein.

$\ddagger$ Per cent of total radioactivity associated with albumin.

the stained electrophoretograms were analyzed by photoelectric densitometry. For adequate detection of radioactivity in the experiments with tracer quantities of radiothyroxine and artificial "extracellular fluid" mix- tures, three replicate electrophoretograms were superimposed upon one another prior to scanning in the automatic strip scanner.

Analysis of the distribution of radioactivity was per- 

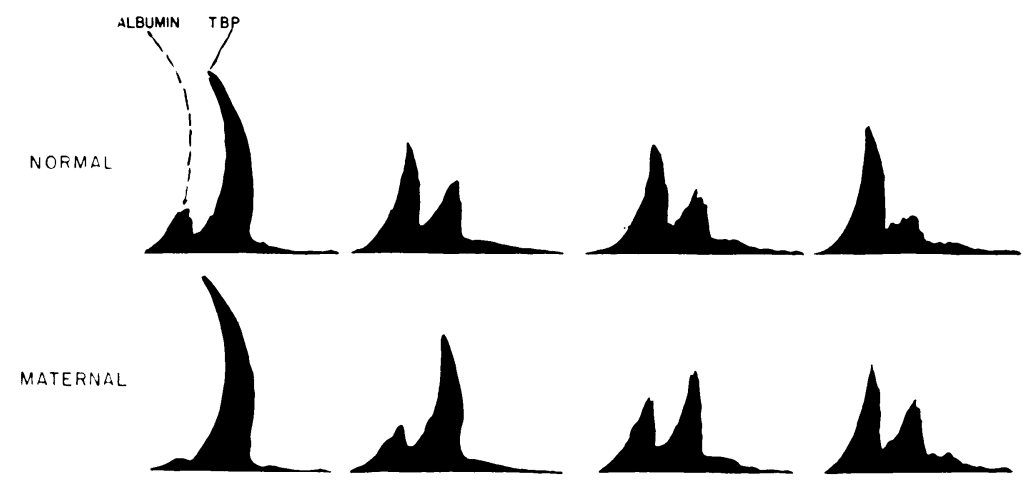

NEONATAL
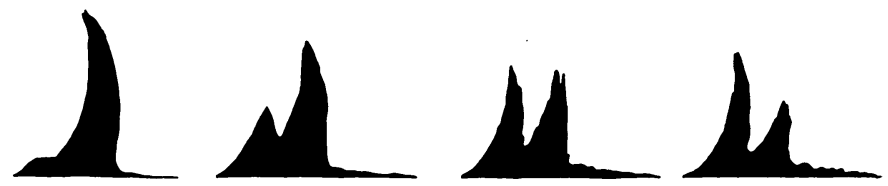

Fig. 1. Compartson of Scans of Radioactivity Obtained from Electrophoretograms of Representative Control, Maternal, anl Neonatal Sera at Variols concentrations of Adped Thyroxine

Concentrations of added thyroxine are, from left to right: $10,48.85$, and $160 \mu \mathrm{g}$. per cent.

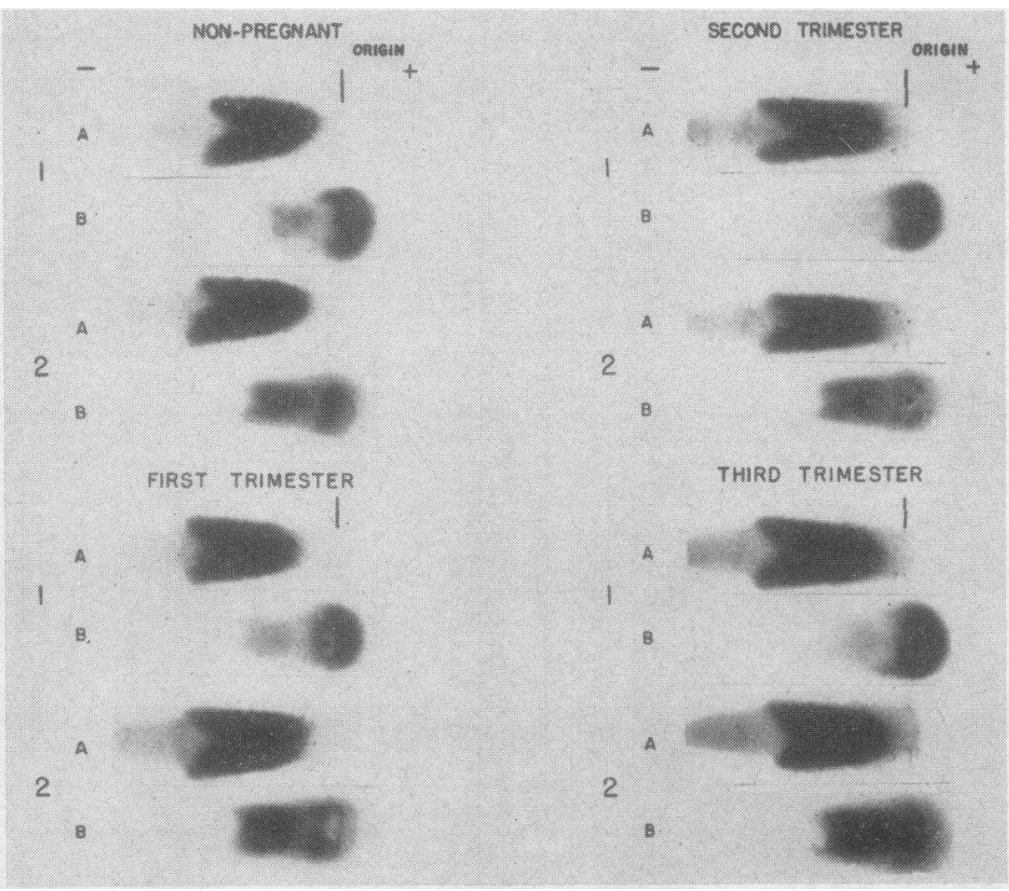

Fig. 2. Elefctrophoretic Migiration of TBP in Sera from Preginant and Non-Preginat Women at PH 4.5

Sera were electrophoresed in Whatman 3 filter-paper at $\mathrm{pH} 4.5$, acetate buffer, ionic strength 0.1 for 24 hours at 180 volts.

1. Concentration of added thyroxine $10 \mu \mathrm{g}$. per cent.

2. Concentration of added thyroxine $48 \mu \mathrm{g}$. per cent.

A. Brom-phenol blue stain.

B. Radioautograph of electrophoretogram obtained prior to staining. 
formed by tracing the original graphic recordings of radioactivity obtained from each individual strip on hard paper of uniform thickness. The total curve, and the peaks representing TBP and albumin were cut from the tracings and weighed, using a semi-automatic analytic balance of $0.05 \mathrm{mg}$. sensitivity. The weights of the curves representing radioactivity bound to albumin and to TBP were expressed as percentages of the total curve weight. This technique allowed rapid and accurate integration of the curves of radioactivity obtained.

Counting rates for individual experiments ranged from 3,000 to 15,000 counts per minute, depending on the specific activity of the radioactive thyroxine used. Background counting rates averaged 16 counts per minute. A counting accuracy of 3 per cent or greater was achieved.

\section{RESULTS}

\section{Normal pregnancy (Table $I)^{7}$}

During electrophoresis at $\mathrm{pH} 8.6$ and at $\mathrm{pH} 4.5$ radiothyroxine added to sera of both pregnant and non-pregnant women displayed identical mobility (Figures 1,2). However, at $\mathrm{pH} \mathrm{8.6,} \mathrm{in}$ sera from pregnant subjects in each of the trimesters, as well as from the pregnant group considered as a whole, and at each concentration of added thyroxine, the percentage of radiothyroxine associated with TBP was significantly greater, and the percentage of radiothyroxine associated with albumin was significantly less than corresponding values in the control sera $(P<0.001)$. Significant differences between individual trimesters could not be discerned, except in the case of the lowest concentration of thyroxine, in which TBPbound thyroxine in the second trimester exceeded that in the first $(P<0.05)$. Poor electrophoretic separation of albumin and $\mathrm{TBP}$ at $\mathrm{pH} 4.5$ precluded comparable quantitative analysis of the binding distribution at this $\mathrm{pH}$. However, it was possible to demonstrate, at $\mathrm{pH} 4.5$, that progressive displacement of radiothyroxine from TBP

${ }^{7}$ Data are presented in terms of the percentage of thyroxine bound to TBP and albumin at varying concentrations of added thyroxine. Since endogenous and exogenous thyroxine are in equilibrium, it is evident that the partition of radiothyroxine in serum depends upon the total concentration of both exogenous and endogenous thyroxine $(24,26)$. Because of the individual variation in endogenous PBI, no attempt was made to present the total thyroxine concentration in each serum following supplementation. It is apparent, however, that since PBI's are greater than normal in sera from pregnant women, the significance of observed differences in the partition of thyroxine is enhanced.

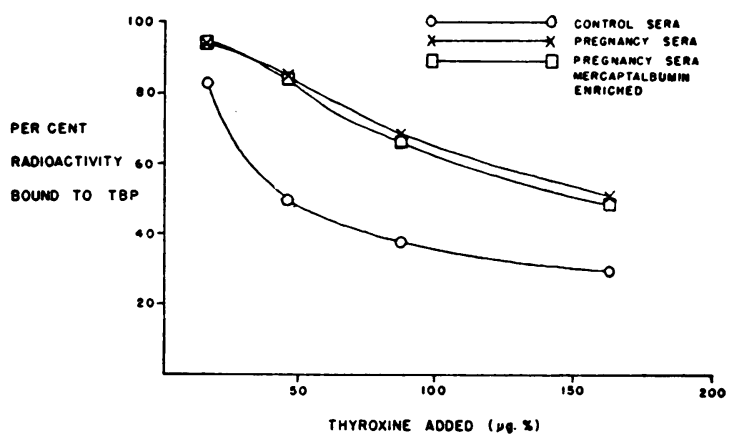

Fig. 3. Per Cent Thyroxine Bound to TBP at Various Concentrations of Added Thyroxine

Comparison of sera of pregnant women before and after enrichment with mercaptalbumin with sera of nonpregnant women.

onto albumin occurred with increasing concentrations of added stable thyroxine (Figure 2).

In Table II are compiled the values for per cent thyroxine bound to TBP and to albumin when all the samples of sera from the same subjects described in Table I were supplemented gravimetrically with mercaptalbumin in amounts sufficient to achieve albumin concentrations of approximately $4.6 \mathrm{gm}$. per cent. No significant difference was discernible in the percentage of thyroxine bound to either TBP or albumin in unsupplemented and supplemented sera (Figure 3 ). However, pure solutions of mercaptalbumin exhibited a high binding affinity for thyroxine since,
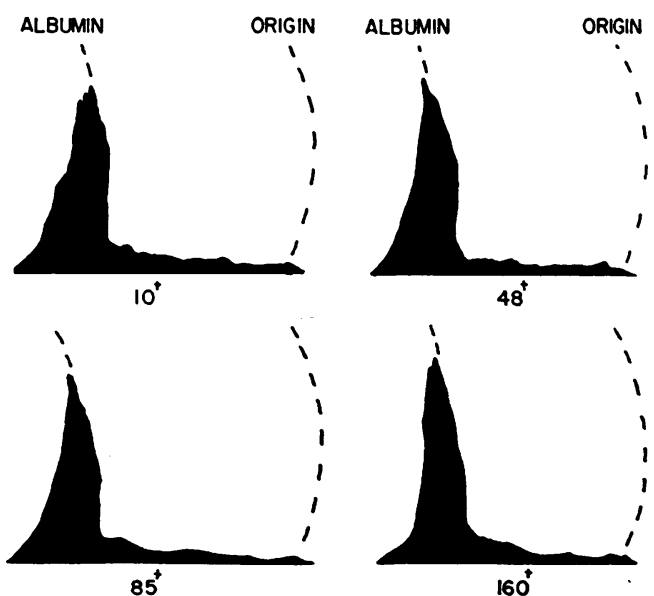

Fig. 4. Thyroxine-Binding by Mercaptalbumin at Various Concentrations of Added Thyroxine

Mercaptalbumin, $2.0 \mathrm{gm} . / 100 \mathrm{ml}$. of $0.85 \mathrm{per}$ cent saline, was electrophoresed in Whatman 3 filter-paper at $\mathrm{pH} 8.6$, barbital buffer, ionic strength 0.05 for 16 hours at 120 volts. 
TABLE II

Distribution of thyroxine between TBP and albumin during filter-paper electrophoresis of sera from pregnant women (effect of in vitro supplementation of sera with mercaptalbumin *)

\begin{tabular}{|c|c|c|c|c|c|c|c|c|c|}
\hline \multirow[b]{3}{*}{ Subject } & \multicolumn{8}{|c|}{ Thyroxine added (ug./100 $\mathrm{ml}.) \dagger$} & \multirow{3}{*}{ 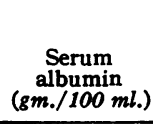 } \\
\hline & \multicolumn{2}{|c|}{10} & \multicolumn{2}{|c|}{48} & \multicolumn{2}{|c|}{85} & \multicolumn{2}{|c|}{160} & \\
\hline & TBPF & A\& & TBP & $\mathbf{A}$ & TBP & $\mathbf{A}$ & TBP & $\mathbf{A}$ & \\
\hline \multicolumn{10}{|c|}{ Non-pregnant Women } \\
\hline $\begin{array}{l}1 \\
2 \\
3 \\
4 \\
5 \\
6 \\
7 \\
8 \\
9\end{array}$ & $\begin{array}{l}89.2 \\
87.3 \\
81.1 \\
85.4 \\
80.7 \\
77.5 \\
82.7 \\
78.5 \\
78.2\end{array}$ & $\begin{array}{r}7.5 \\
8.7 \\
13.4 \\
11.9 \\
13.8 \\
17.8 \\
17.8 \\
15.5 \\
17.0\end{array}$ & $\begin{array}{l}55.0 \\
56.6 \\
47.5 \\
50.0 \\
48.3 \\
42.0 \\
42.0 \\
53.9 \\
44.7\end{array}$ & $\begin{array}{l}38.6 \\
37.8 \\
47.6 \\
42.2 \\
45.2 \\
51.1 \\
51.1 \\
38.8 \\
50.4\end{array}$ & $\begin{array}{l}41.6 \\
41.9 \\
34.5 \\
37.6 \\
35.7 \\
33.5 \\
33.5 \\
38.7 \\
34.0\end{array}$ & $\begin{array}{l}49.4 \\
51.3 \\
59.6 \\
56.4 \\
58.8 \\
60.5 \\
60.5 \\
53.7 \\
58.1\end{array}$ & $\begin{array}{l}32.2 \\
34.6 \\
22.5 \\
33.3 \\
26.7 \\
29.6 \\
29.6 \\
29.1 \\
25.7\end{array}$ & $\begin{array}{l}57.9 \\
59.1 \\
71.2 \\
63.7 \\
66.2 \\
62.4 \\
62.4 \\
61.8 \\
67.2\end{array}$ & $\begin{array}{l}4.6 \\
4.5 \\
4.6 \\
4.6 \\
4.6 \\
4.6 \\
4.5 \\
4.5 \\
4.6\end{array}$ \\
\hline $\begin{array}{l}\text { Mean } \\
\text { Std. dev. }\end{array}$ & $\begin{array}{r}82.3 \\
3.7\end{array}$ & $\begin{array}{r}13.1 \\
3.5\end{array}$ & $\begin{array}{r}50.6 \\
5.5\end{array}$ & $\begin{array}{r}43.6 \\
5.5\end{array}$ & $\begin{array}{r}43.1 \\
4.0\end{array}$ & $\begin{array}{r}54.9 \\
5.0\end{array}$ & $\begin{array}{r}29.8 \\
4.3 \\
\end{array}$ & $\begin{array}{r}62.8 \\
4.9 \\
\end{array}$ & \\
\hline \multicolumn{10}{|c|}{ First Trimester ( 6 to 13 weeks, inclusive) } \\
\hline $\begin{array}{l}1 \\
2 \\
3 \\
4 \\
5 \\
6\end{array}$ & $\begin{array}{l}95.0 \\
84.6 \\
91.6 \\
89.3 \\
88.1 \\
87.7\end{array}$ & $\begin{array}{l}4.1 \\
2.9 \\
4.6 \\
5.8 \\
7.2 \\
6.8\end{array}$ & $\begin{array}{l}80.1 \\
89.6 \\
86.6 \\
78.6 \\
75.9 \\
77.6\end{array}$ & $\begin{array}{r}14.9 \\
19.3 \\
15.4 \\
17.7 \\
8.8 \\
14.7\end{array}$ & $\begin{array}{l}62.9 \\
57.6 \\
71.5 \\
63.9 \\
58.3 \\
62.4\end{array}$ & $\begin{array}{l}32.4 \\
38.8 \\
23.3 \\
31.2 \\
35.8 \\
30.9\end{array}$ & $\begin{array}{l}46.8 \\
44.8 \\
56.9 \\
44.7 \\
44.3 \\
47.0\end{array}$ & $\begin{array}{l}48.8 \\
50.9 \\
37.8 \\
48.6 \\
47.1 \\
44.8\end{array}$ & $\begin{array}{l}4.6 \\
4.7 \\
4.6 \\
4.6 \\
4.6 \\
4.6\end{array}$ \\
\hline $\begin{array}{l}\text { Mean } \\
\text { Std. dev. }\end{array}$ & $\begin{array}{r}90.2 \\
2.7\end{array}$ & $\begin{array}{l}5.2 \\
1.7\end{array}$ & $\begin{array}{r}81.4 \\
5.5\end{array}$ & $\begin{array}{r}15.1 \\
3.6\end{array}$ & $\begin{array}{r}62.8 \\
4.2 \\
\end{array}$ & $\begin{array}{r}32.1 \\
5.2 \\
\end{array}$ & $\begin{array}{r}47.4 \\
4.8 \\
\end{array}$ & $\begin{array}{r}46.4 \\
4.6\end{array}$ & \\
\hline \multicolumn{10}{|c|}{ Second Trimester (14 to 27 weeks, inclusive) } \\
\hline $\begin{array}{r}7 \\
8 \\
9 \\
10 \\
11 \\
12 \\
13 \\
14\end{array}$ & $\begin{array}{l}94.5 \\
93.4 \\
93.0 \\
93.0 \\
94.0 \\
89.8 \\
90.5 \\
92.8 \\
\end{array}$ & $\begin{array}{l}2.7 \\
3.9 \\
4.5 \\
3.0 \\
3.4 \\
6.4 \\
5.9 \\
4.9 \\
\end{array}$ & $\begin{array}{l}\mathbf{7 5 . 3} \\
82.4 \\
80.2 \\
80.4 \\
86.8 \\
78.8 \\
\mathbf{8 0 . 1} \\
77.5 \\
\end{array}$ & $\begin{array}{r}13.9 \\
9.9 \\
20.4 \\
12.9 \\
13.8 \\
17.0 \\
15.8 \\
17.8 \\
\end{array}$ & $\begin{array}{l}59.8 \\
70.7 \\
54.5 \\
62.5 \\
61.0 \\
60.3 \\
60.6 \\
56.2\end{array}$ & $\begin{array}{l}30.1 \\
26.1 \\
39.8 \\
30.9 \\
31.8 \\
34.5 \\
24.9 \\
37.0 \\
\end{array}$ & $\begin{array}{l}46.9 \\
50.6 \\
41.1 \\
47.1 \\
43.1 \\
42.9 \\
43.0 \\
44.9 \\
\end{array}$ & $\begin{array}{l}43.7 \\
41.4 \\
51.5 \\
45.3 \\
45.3 \\
52.7 \\
52.4 \\
48.6\end{array}$ & $\begin{array}{l}4.7 \\
4.6 \\
4.6 \\
4.6 \\
4.6 \\
4.6 \\
4.7 \\
4.6\end{array}$ \\
\hline $\begin{array}{l}\text { Mean } \\
\text { Std. dev. }\end{array}$ & $\begin{array}{r}92.6 \\
2.8 \\
\end{array}$ & $\begin{array}{l}4.4 \\
1.4 \\
\end{array}$ & $\begin{array}{r}80.2 \\
3.4 \\
\end{array}$ & $\begin{array}{r}15.2 \\
3.3 \\
\end{array}$ & $\begin{array}{r}60.7 \\
4.8 \\
\end{array}$ & $\begin{array}{r}31.9 \\
5.1 \\
\end{array}$ & $\begin{array}{r}44.9 \\
3.1 \\
\end{array}$ & $\begin{array}{r}47.6 \\
4.3 \\
\end{array}$ & \\
\hline \multicolumn{10}{|c|}{ Third Trimester ( 28 to 40 weeks, inclusive) } \\
\hline $\begin{array}{l}15 \\
16 \\
17 \\
18 \\
19 \\
20 \\
21 \\
22\end{array}$ & $\begin{array}{l}94.1 \\
93.3 \\
94.7 \\
93.6 \\
95.4 \\
91.0 \\
92.1 \\
90.4\end{array}$ & $\begin{array}{l}3.9 \\
4.0 \\
3.1 \\
2.5 \\
2.1 \\
5.1 \\
5.0 \\
5.7\end{array}$ & $\begin{array}{l}83.0 \\
88.2 \\
91.6 \\
90.7 \\
87.1 \\
76.6 \\
74.9 \\
76.6\end{array}$ & $\begin{array}{r}11.7 \\
8.4 \\
5.0 \\
5.1 \\
8.9 \\
17.8 \\
18.0 \\
18.0\end{array}$ & $\begin{array}{l}65.1 \\
70.8 \\
79.6 \\
72.9 \\
67.8 \\
59.8 \\
60.8 \\
57.4\end{array}$ & $\begin{array}{l}29.3 \\
22.6 \\
15.5 \\
20.4 \\
24.5 \\
32.7 \\
33.4 \\
36.1\end{array}$ & $\begin{array}{l}46.3 \\
51.5 \\
56.7 \\
57.4 \\
47.9 \\
45.8 \\
41.3 \\
44.7\end{array}$ & $\begin{array}{l}46.9 \\
39.9 \\
31.3 \\
33.4 \\
41.0 \\
46.9 \\
48.7 \\
48.6\end{array}$ & $\begin{array}{l}4.6 \\
4.7 \\
4.7 \\
4.5 \\
4.6 \\
4.6 \\
4.6 \\
4.6\end{array}$ \\
\hline $\begin{array}{l}\text { Mean } \\
\text { Std. dev. }\end{array}$ & $\begin{array}{r}93.1 \\
1.8\end{array}$ & $\begin{array}{l}3.9 \\
1.3 \\
\end{array}$ & $\begin{array}{r}83.6 \\
6.8\end{array}$ & $\begin{array}{r}11.6 \\
4.2\end{array}$ & $\begin{array}{r}66.8 \\
7.5\end{array}$ & $\begin{array}{r}26.8 \\
7.2\end{array}$ & $\begin{array}{r}48.9 \\
5.8\end{array}$ & $\begin{array}{r}42.1 \\
6.9\end{array}$ & \\
\hline \multicolumn{10}{|c|}{ Entire Pregnant Group } \\
\hline $\begin{array}{l}\text { Mean } \\
\text { Std. dev. }\end{array}$ & $\begin{array}{r}92.1 \\
2.3\end{array}$ & $\begin{array}{l}4.4 \\
1.3\end{array}$ & $\begin{array}{r}81.6 \\
5.3\end{array}$ & $\begin{array}{r}13.9 \\
4.5\end{array}$ & $\begin{array}{r}63.5 \\
6.3\end{array}$ & $\begin{array}{r}30.1 \\
6.2\end{array}$ & $\begin{array}{r}47.1 \\
4.2\end{array}$ & $\begin{array}{r}45.3 \\
5.8\end{array}$ & \\
\hline
\end{tabular}

* Same patients as in Table I.

$\dagger$ Based on original gravimetric addition.

$¥$ Per cent of total radioactivity associated with the thyroxine-binding protein.

$\$$ Per cent of total radioactivity associated with albumin. 
TABLE III

Distribution of thyroxine between TBP and albumin during filter-paper electrophoresis of sera from women in early pregnancy

\begin{tabular}{|c|c|c|c|c|c|c|c|c|}
\hline & \multicolumn{8}{|c|}{ Thyroxine added $(\mu \mathrm{g} . / 100 \mathrm{ml} .)^{*}$} \\
\hline & \multicolumn{2}{|c|}{10} & \multicolumn{2}{|c|}{48} & \multicolumn{2}{|c|}{85} & \multicolumn{2}{|c|}{160} \\
\hline & TBPT & Af & TBP & A & TBP & A & TBP & A \\
\hline \multicolumn{9}{|l|}{ Experiment 1} \\
\hline \multirow{2}{*}{$\begin{array}{l}\text { Control§ } \\
\text { Pregnancy } \\
\text { 21st Postovulatory day }\end{array}$} & 70.0 & 12.5 & 39.5 & 42.8 & 36.8 & 53.7 & 26.1 & 64.9 \\
\hline & 83.5 & 7.0 & 55.3 & 33.3 & 43.3 & 38.5 & 31.6 & 50.6 \\
\hline \multicolumn{9}{|l|}{ Experiment 2} \\
\hline \multirow{2}{*}{$\begin{array}{l}\text { Control§ } \\
\text { Pregnancy } \\
\text { 21st Postovulatory day }\end{array}$} & 73.5 & 14.0 & 42.6 & 38.6 & 28.9 & 59.8 & 24.0 & 64.8 \\
\hline & 85.7 & 7.9 & 56.1 & 35.4 & 39.1 & 40.9 & 27.2 & 51.6 \\
\hline
\end{tabular}

* Based on original gravimetric addition.

+ Per cent of total radioactivity associated with the thyroxine-binding protein.

$\ddagger$ Per cent of total radioactivity associated with albumin.

8. Mean values of 5 non-pregnant women.

at each of the four concentrations of thyroxine employed, at least 80 per cent of added radiothyroxine migrated with the mercaptalbumin during electrophoresis (Figure 4).

Sera obtained from 2 pregnant patients on the estimated twenty-first postovulatory day revealed percentages of thyroxine bound to TBP and to albumin approaching values found in normal pregnancy of longer duration, and differing markedly from values in concurrently electrophoresed sera from non-pregnant controls (Table III).

In serum from the three patients observed dur-

TABLE IV

Distribution of thyroxine between TBP and albumin during filter-paper electrophoresis of sera from women in the puerperium

\begin{tabular}{|c|c|c|c|c|c|c|c|c|c|}
\hline & \multicolumn{8}{|c|}{ Thyroxine added $(\mu \mathrm{g} . / 100 \mathrm{ml} .)^{*}$} & \multirow{3}{*}{$\begin{array}{c}\text { Serum } \\
\text { PBI } \\
(\mu g . / 100 m l .)\end{array}$} \\
\hline & \multicolumn{2}{|c|}{10} & \multicolumn{2}{|c|}{48} & \multicolumn{2}{|c|}{85} & \multicolumn{2}{|c|}{160} & \\
\hline & TBPY & At & TBP & $\mathbf{A}$ & TBP & $\mathbf{A}$ & TBP & $\mathbf{A}$ & \\
\hline \multicolumn{10}{|c|}{ Non-pregnant Women } \\
\hline $\begin{array}{l}1 \\
2 \\
3\end{array}$ & $\begin{array}{l}79.1 \\
80.2 \\
78.4\end{array}$ & $\begin{array}{l}17.1 \\
16.8 \\
15.9\end{array}$ & $\begin{array}{l}54.2 \\
53.7 \\
55.1\end{array}$ & $\begin{array}{l}38.7 \\
37.9 \\
38.4\end{array}$ & $\begin{array}{l}46.0 \\
44.0 \\
47.4\end{array}$ & $\begin{array}{l}48.1 \\
49.8 \\
47.6\end{array}$ & $\begin{array}{l}38.4 \\
39.0 \\
37.9\end{array}$ & $\begin{array}{l}56.7 \\
56.9 \\
55.1\end{array}$ & $\begin{array}{l}5.0 \\
5.2 \\
4.8\end{array}$ \\
\hline \multicolumn{10}{|c|}{ Puerperal Subject 1} \\
\hline $\begin{array}{l}\text { Term } \\
1 \text { Week } \\
3 \text { Weeks } \\
5 \text { Weeks }\end{array}$ & $\begin{array}{l}95.0 \\
94.2 \\
92.6 \\
88.7\end{array}$ & $\begin{array}{l}3.4 \\
4.8 \\
5.1 \\
8.4\end{array}$ & $\begin{array}{l}89.8 \\
78.1 \\
70.8 \\
63.7\end{array}$ & $\begin{array}{r}7.2 \\
18.1 \\
20.9 \\
29.8\end{array}$ & $\begin{array}{l}69.4 \\
60.5 \\
56.8 \\
51.3\end{array}$ & $\begin{array}{l}23.7 \\
38.4 \\
41.4 \\
46.6\end{array}$ & $\begin{array}{l}52.4 \\
47.9 \\
45.5 \\
42.1\end{array}$ & $\begin{array}{l}42.4 \\
47.4 \\
48.3 \\
50.1\end{array}$ & $\begin{array}{l}9.0 \\
8.4 \\
6.6 \\
5.9\end{array}$ \\
\hline \multicolumn{10}{|c|}{ Puerperal Subject 2} \\
\hline $\begin{array}{l}\text { Term } \\
1 \text { Week } \\
3 \text { Weeks } \\
5 \text { Weeks }\end{array}$ & $\begin{array}{l}95.1 \\
94.0 \\
94.5 \\
91.6\end{array}$ & $\begin{array}{l}2.8 \\
5.1 \\
3.6 \\
5.6\end{array}$ & $\begin{array}{l}85.2 \\
77.6 \\
72.6 \\
65.4\end{array}$ & $\begin{array}{l}10.9 \\
16.8 \\
21.4 \\
26.4\end{array}$ & $\begin{array}{l}69.1 \\
59.2 \\
60.1 \\
50.8\end{array}$ & $\begin{array}{l}21.6 \\
31.8 \\
28.0 \\
40.9\end{array}$ & $\begin{array}{l}59.2 \\
52.2 \\
49.1 \\
41.5\end{array}$ & $\begin{array}{l}32.2 \\
31.7 \\
38.4 \\
43.7\end{array}$ & $\begin{array}{l}8.5 \\
7.8 \\
5.8 \\
5.5\end{array}$ \\
\hline \multicolumn{10}{|c|}{ Puerperal Subject 3} \\
\hline $\begin{array}{l}\text { Term } \\
1 \text { Week } \\
3 \text { Weeks } \\
5 \text { Weeks }\end{array}$ & $\begin{array}{l}94.4 \\
92.3 \\
87.9 \\
84.8\end{array}$ & $\begin{array}{l}4.0 \\
5.1 \\
7.2 \\
9.1\end{array}$ & $\begin{array}{l}87.1 \\
76.4 \\
77.1 \\
69.2\end{array}$ & $\begin{array}{r}8.4 \\
16.9 \\
14.1 \\
21.7\end{array}$ & $\begin{array}{l}70.2 \\
58.1 \\
52.6 \\
52.3\end{array}$ & $\begin{array}{l}22.4 \\
32.8 \\
34.7 \\
37.8\end{array}$ & $\begin{array}{l}60.0 \\
48.0 \\
44.8 \\
41.9\end{array}$ & $\begin{array}{l}29.8 \\
44.7 \\
47.5 \\
50.6\end{array}$ & $\begin{array}{l}7.7 \\
6.9 \\
6.0 \\
4.6\end{array}$ \\
\hline
\end{tabular}

* Based on original gravimetric addition.

+ Per cent of total radioactivity associated with the thyroxine-binding protein.

$\ddagger$ Per cent of total radioactivity associated with albumin. 
ing the puerperium, thyroxine-binding by TBP was approaching, but had not yet returned to normal non-pregnant values by the end of the fifth post-partum week (Table IV).

Despite considerable variation, concentrations of SPI were significantly greater than normal during the first and subsequent trimesters. Significant differences between individual trimesters were also noted, the mean of third trimester concentrations of SPI being the highest and the mean of the second trimester values being the lowest (Table I). The concentrations of SPI in the puerperium decreased to control values by the fifth post-partum week (Table IV).

Except in the first trimester, the concentrations of total protein in the sera obtained from pregnant women were slightly lower than those of the controls $(P<0.02)$. Significant reduction in the concentration of albumin in sera from normally pregnant women was apparent in all three trimesters $(P<0.01)$ (Table $I)$.

Thyroxine-binding by TBP in serum from all of the 6 patients with threatened or inevitable abortion was not assayed concurrently. Therefore, in order to intercompare results among the $6 \mathrm{pa}$ tients, the percentage of thyroxine bound to TBP in these patients has been expressed as a percentage of the corresponding values in concurrently analyzed sera from normal, non-pregnant controls (Table V). These values were then compared with comparably calculated percentages for pregnant women in the first trimester (derived from the data in Table I). The results then fell into two categories. In sera from four of the patients, alterations in the partition of thyroxine of a degree characteristic of normal pregnancy were not observed. These patients either aborted dead fetuses spontaneously or, following development of negative $A-Z$ tests and withdrawal of the blood sample to be analyzed, underwent dilatation and curettage for incomplete abortion. Two of the 6 patients revealed changes in the partition of thyroxine consistent with normal pregnancy of similar duration. In spite of vaginal bleeding sufficient to warrant hospitalization with a diagnosis of threatened abortion, one patient is in her ninth month of apparently normal pregnancy and the other recently underwent normal parturition.

Table VI and Figure 1 present data obtained during a single experiment comparing sera obtained at term, sera of the corresponding newborn, and sera from non-pregnant controls. Neonatal concentrations of SPI (7.9 $\pm 0.8 \mu \mathrm{g}$. per cent) (mean \pm standard deviation) were significantly greater than control values $(P<0.05)$, but did not differ significantly from maternal concentrations ( $8.5 \pm 0.5 \mu \mathrm{g}$. per cent). In maternal sera, all values of the percentage of thyroxine bound

TABLE V

Distribution of thyroxine between TBP and albumin during filter-paper electrophoresis of sera from patients with a diagnosis of threatened or inevitable abortion *

\begin{tabular}{|c|c|c|c|c|c|c|c|c|}
\hline & \multicolumn{4}{|c|}{ Thyroxine added $(\mu \mathrm{g} . / 100 \mathrm{ml}.) \dagger$} & \multirow{2}{*}{ 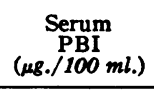 } & \multirow{2}{*}{$\begin{array}{c}\text { Serum } \\
\text { total protein } \\
(\mathrm{gm.} / 100 \mathrm{ml} .)\end{array}$} & \multirow{2}{*}{$\underset{\substack{\text { Serum } \\
\text { albumin } \\
(\mathrm{gm.} . / 100 \mathrm{ml} .)}}{ }$} & \multirow{2}{*}{$\begin{array}{c}\text { Week } \\
\text { of } \\
\text { pregnancy }\end{array}$} \\
\hline & 10 & 48 & 85 & 160 & & & & \\
\hline \multicolumn{9}{|c|}{ Control } \\
\hline & 100.0 & 100.0 & 100.0 & 100.0 & 5.3 & 6.8 & 4.1 & \\
\hline \multicolumn{9}{|c|}{ Pregnancy (First Trimester) } \\
\hline & 112.5 & 160.9 & 145.7 & 159.1 & 8.1 & 6.4 & 3.5 & $11 \ddagger$ \\
\hline \multicolumn{9}{|c|}{ Threatened or Inevitable Abortion } \\
\hline $\begin{array}{l}1 \\
2 \\
3 \\
4 \\
5 \\
6\end{array}$ & $\begin{array}{l}100.0 \\
100.0 \\
122.8 \\
110.2 \\
120.68 \\
130.48\end{array}$ & $\begin{array}{r}118.0 \\
96.9 \\
121.5 \\
114.9 \\
147.4 \\
168.8\end{array}$ & $\begin{array}{r}109.0 \\
115.4 \\
111.3 \\
98.1 \\
134.7 \\
169.7\end{array}$ & $\begin{array}{r}110.4 \\
115.0 \\
98.9 \\
101.4 \\
174.5 \\
214.5\end{array}$ & $\begin{array}{l}5.5 \\
4.8 \\
6.0 \\
5.8 \\
5.8 \\
7.7\end{array}$ & $\begin{array}{l}6.5 \\
7.0 \\
7.1 \\
7.0 \\
7.1 \\
6.8\end{array}$ & $\begin{array}{l}3.8 \\
4.2 \\
4.4 \\
3.8 \\
4.2 \\
4.3\end{array}$ & $\begin{array}{r}10 \\
13 \\
12 \\
15 \\
5 \\
12\end{array}$ \\
\hline
\end{tabular}

* Percentage of radioactivity associated with TBP at varying concentrations of stable thyroxine expressed as per cent of control values for the individual experiment.

$\dagger$ Based on original gravimetric addition.

$\neq$ Mean duration of pregnancy in first trimester subjects of Table I.

Pregnancy not interrupted in these cases. 
TABLE VI

Distribution of thyroxine between $T B P$ and albumin during filter-paper electrophoresis of sera from pregnant women at term and from their respective newborn

\begin{tabular}{|c|c|c|c|c|c|c|c|c|c|c|c|}
\hline \multirow[b]{3}{*}{ Subject } & \multicolumn{8}{|c|}{ Thyroxine added ( $\mu \mathrm{g} . / 100 \mathrm{ml}.)^{*}$} & \multirow{3}{*}{$\begin{array}{c}\text { Serum } \\
\text { PBI } \\
\text { (us./100 ml.) }\end{array}$} & \multirow{3}{*}{$\begin{array}{c}\text { Serum } \\
\text { total } \\
\text { protein } \\
(\mathrm{gm} . / 100 \mathrm{ml} .)\end{array}$} & \multirow{3}{*}{$\underset{\substack{\text { Serum } \\
\text { albumin } \\
(\mathrm{gm.} / 100 \mathrm{ml} .)}}{{ }^{\prime}}$} \\
\hline & \multicolumn{2}{|c|}{10} & \multicolumn{2}{|c|}{48} & \multicolumn{2}{|c|}{85} & \multicolumn{2}{|c|}{160} & & & \\
\hline & TBP† & At & TBP & $\mathbf{A}$ & TBP & $\mathbf{A}$ & TBP & $\mathbf{A}$ & & & \\
\hline \multicolumn{12}{|c|}{ Non-pregnant Women } \\
\hline $\begin{array}{l}1 \\
2 \\
3 \\
4 \\
5 \\
6 \\
7 \\
8\end{array}$ & $\begin{array}{l}70.3 \\
74.0 \\
79.7 \\
76.7 \\
77.8 \\
71.1 \\
83.7 \\
72.3\end{array}$ & $\begin{array}{l}23.5 \\
20.0 \\
17.7 \\
18.9 \\
16.3 \\
22.1 \\
10.1 \\
24.8\end{array}$ & $\begin{array}{l}36.8 \\
42.1 \\
40.2 \\
46.3 \\
51.6 \\
39.6 \\
55.0 \\
38.0\end{array}$ & $\begin{array}{l}54.5 \\
49.6 \\
48.3 \\
44.0 \\
39.4 \\
53.0 \\
33.2 \\
59.6\end{array}$ & $\begin{array}{l}27.7 \\
32.4 \\
34.3 \\
33.1 \\
41.4 \\
31.5 \\
40.7 \\
30.0\end{array}$ & $\begin{array}{l}62.7 \\
61.0 \\
51.8 \\
54.7 \\
47.6 \\
58.4 \\
53.9 \\
63.4\end{array}$ & $\begin{array}{l}18.2 \\
22.4 \\
25.7 \\
23.9 \\
33.6 \\
24.3 \\
35.3 \\
25.8\end{array}$ & $\begin{array}{l}71.6 \\
67.7 \\
60.6 \\
65.5 \\
52.0 \\
64.6 \\
56.3 \\
67.2\end{array}$ & $\begin{array}{l}\mathbf{5 . 0} \\
\mathbf{5 . 1} \\
\mathbf{5 . 0} \\
5.9 \\
5.4 \\
4.6 \\
5.0 \\
6.0\end{array}$ & $\begin{array}{l}8.0 \\
7.1 \\
6.9 \\
6.3 \\
7.2 \\
7.0 \\
6.7 \\
6.4\end{array}$ & $\begin{array}{l}4.8 \\
4.0 \\
4.0 \\
3.9 \\
4.5 \\
4.2 \\
4.4 \\
4.0\end{array}$ \\
\hline $\begin{array}{l}\text { Mean } \\
\text { Std. dev. }\end{array}$ & $\begin{array}{r}75.7 \\
4.5\end{array}$ & $\begin{array}{r}19.2 \\
4.6\end{array}$ & $\begin{array}{r}43.7 \\
6.6\end{array}$ & $\begin{array}{r}47.7 \\
8.5\end{array}$ & $\begin{array}{r}33.9 \\
4.8\end{array}$ & $\begin{array}{r}56.7 \\
5.6\end{array}$ & $\begin{array}{r}26.2 \\
5.7\end{array}$ & $\begin{array}{r}63.2 \\
6.5\end{array}$ & $\begin{array}{l}5.3 \\
0.5\end{array}$ & $\begin{array}{l}6.9 \\
0.5\end{array}$ & $\begin{array}{l}4.2 \\
0.3\end{array}$ \\
\hline \multicolumn{12}{|c|}{ Maternal, at Term } \\
\hline $\begin{array}{l}1 \\
2 \\
3 \\
4 \\
5 \\
6 \\
7 \\
8\end{array}$ & $\begin{array}{l}95.2 \\
91.0 \\
93.0 \\
96.2 \\
95.6 \\
93.9 \\
86.3 \\
94.5\end{array}$ & $\begin{array}{l}3.1 \\
5.7 \\
3.2 \\
1.8 \\
1.6 \\
3.7 \\
3.5 \\
3.4\end{array}$ & $\begin{array}{l}75.1 \\
68.7 \\
74.1 \\
86.7 \\
90.2 \\
86.7 \\
82.9 \\
82.8\end{array}$ & $\begin{array}{r}11.2 \\
22.6 \\
23.6 \\
8.3 \\
5.9 \\
8.9 \\
9.9 \\
11.7\end{array}$ & $\begin{array}{l}58.3 \\
50.0 \\
58.4 \\
68.8 \\
71.3 \\
72.8 \\
68.7 \\
66.0\end{array}$ & $\begin{array}{l}30.5 \\
34.1 \\
30.6 \\
21.5 \\
20.3 \\
22.8 \\
21.6 \\
29.1\end{array}$ & $\begin{array}{l}46.1 \\
39.8 \\
46.9 \\
58.7 \\
61.1 \\
51.4 \\
54.1 \\
51.5\end{array}$ & $\begin{array}{l}42.3 \\
44.1 \\
40.7 \\
34.4 \\
28.2 \\
44.9 \\
34.0 \\
42.9\end{array}$ & $\begin{array}{l}8.6 \\
9.0 \\
9.5 \\
8.4 \\
7.8 \\
8.5 \\
8.2 \\
8.0\end{array}$ & $\begin{array}{l}6.2 \\
6.0 \\
6.4 \\
6.0 \\
6.7 \\
6.4 \\
6.0 \\
6.2\end{array}$ & $\begin{array}{l}3.3 \\
3.3 \\
3.4 \\
2.7 \\
3.4 \\
3.5 \\
3.9 \\
3.3\end{array}$ \\
\hline $\begin{array}{l}\text { Mean } \\
\text { Std. dev. }\end{array}$ & $\begin{array}{r}93.2 \\
3.2\end{array}$ & $\begin{array}{l}3.3 \\
1.3\end{array}$ & $\begin{array}{r}80.9 \\
7.5\end{array}$ & $\begin{array}{r}12.8 \\
6.6\end{array}$ & $\begin{array}{r}64.3 \\
7.9\end{array}$ & $\begin{array}{r}26.3 \\
5.3\end{array}$ & $\begin{array}{r}51.2 \\
6.9\end{array}$ & $\begin{array}{r}38.9 \\
6.0\end{array}$ & $\begin{array}{l}8.5 \\
0.5\end{array}$ & $\begin{array}{l}6.2 \\
0.3\end{array}$ & $\begin{array}{l}3.3 \\
0.3\end{array}$ \\
\hline \multicolumn{12}{|c|}{ Corresponding Newborn } \\
\hline $\begin{array}{l}1 \\
2 \\
3 \\
4 \\
5 \\
6 \\
7 \\
8\end{array}$ & $\begin{array}{l}91.5 \\
98.3 \\
89.4 \\
97.1 \\
90.8 \\
92.1 \\
88.4 \\
93.2\end{array}$ & $\begin{array}{l}6.0 \\
7.5 \\
7.5 \\
2.5 \\
3.9 \\
4.2 \\
5.4 \\
5.1\end{array}$ & $\begin{array}{l}67.7 \\
65.5 \\
62.3 \\
75.0 \\
80.5 \\
63.8 \\
68.5 \\
68.2\end{array}$ & $\begin{array}{l}27.6 \\
29.0 \\
30.8 \\
20.8 \\
15.2 \\
33.5 \\
25.3 \\
30.7\end{array}$ & $\begin{array}{l}47.1 \\
45.0 \\
52.3 \\
59.8 \\
55.1 \\
57.0 \\
52.9 \\
49.6\end{array}$ & $\begin{array}{l}44.7 \\
45.1 \\
36.2 \\
34.5 \\
35.5 \\
37.0 \\
42.0 \\
43.9\end{array}$ & $\begin{array}{l}34.3 \\
37.9 \\
47.2 \\
49.2 \\
52.4 \\
40.3 \\
40.9 \\
44.4\end{array}$ & $\begin{array}{l}54.4 \\
56.0 \\
43.1 \\
42.6 \\
36.6 \\
53.0 \\
53.8 \\
48.4\end{array}$ & $\begin{array}{l}9.0 \\
9.2 \\
6.7 \\
7.5 \\
8.3 \\
7.0 \\
7.6 \\
7.8\end{array}$ & $\begin{array}{l}6.4 \\
7.1 \\
5.4 \\
6.1 \\
5.7 \\
6.2 \\
6.2 \\
5.7\end{array}$ & $\begin{array}{l}3.4 \\
3.4 \\
3.4 \\
3.3 \\
3.5 \\
3.4 \\
3.8 \\
3.3\end{array}$ \\
\hline $\begin{array}{l}\text { Mean } \\
\text { Std. dev. }\end{array}$ & $\begin{array}{r}91.5 \\
2.8\end{array}$ & $\begin{array}{l}5.3 \\
1.7\end{array}$ & $\begin{array}{r}68.9 \\
6.0\end{array}$ & $\begin{array}{r}26.6 \\
6.0\end{array}$ & $\begin{array}{r}52.4 \\
5.0\end{array}$ & $\begin{array}{r}39.9 \\
4.5\end{array}$ & $\begin{array}{r}43.3 \\
6.1\end{array}$ & $\begin{array}{r}48.5 \\
7.0\end{array}$ & $\begin{array}{l}7.9 \\
0.9\end{array}$ & $\begin{array}{l}6.1 \\
0.5\end{array}$ & $\begin{array}{l}3.4 \\
0.2\end{array}$ \\
\hline
\end{tabular}

* Based on original gravimetric addition.

+ Per cent of total radioactivity associated with the thyroxine-binding protein.

$\ddagger$ Per cent of total radioactivity associated with albumin.

TABLE VII

Distribution of thyroxine between TBP and albumin during filter-paper electrophoresis of dilute sera

\begin{tabular}{|c|c|c|c|c|c|}
\hline & TBP* & At & $\underset{(\mu g . / 100 \mathrm{ml} .)}{\text { PBI } \ddagger}$ & $\underset{\substack{\text { Total } \\
\text { protein } \\
(\mathrm{gm.} / 100 \mathrm{ml} .)}}{\text { (10) }}$ & $\underset{(\mathrm{gm} . / 100 \mathrm{ml} .)}{\text { Albumin }}$ \\
\hline \multicolumn{6}{|c|}{ Non-pregnant Control } \\
\hline $\begin{array}{l}\text { Undilute serum } \\
\text { Dilute serum }\end{array}$ & $\begin{array}{l}80.3 \\
48.6\end{array}$ & $\begin{array}{l}10.5 \\
27.1\end{array}$ & $\begin{array}{l}5.6 \\
2.2\end{array}$ & $\begin{array}{l}6.4 \\
1.4\end{array}$ & $\begin{array}{l}4.4 \\
1.1\end{array}$ \\
\hline \multicolumn{6}{|l|}{ Pregnant } \\
\hline $\begin{array}{l}\text { Undilute serum } \\
\text { Dilute serum }\end{array}$ & $\begin{array}{l}89.9 \\
70.4\end{array}$ & $\begin{array}{r}4.2 \\
13.9\end{array}$ & $\begin{array}{l}8.1 \\
2.3\end{array}$ & $\begin{array}{l}5.6 \\
1.3\end{array}$ & $\begin{array}{l}4.0 \\
1.0\end{array}$ \\
\hline
\end{tabular}

* Per cent of total radioactivity associated with the thyroxine-binding protein.

+ Per cent of total radioactivity associated with albumin.

$\ddagger$ Chemically-determined composition of the final mixtures which were electrophoresed on filter-paper. For details of the preparation of these mixtures, see text. 
to TBP were significantly greater than corresponding values among controls $(P<0.001)$. In the case of the newborn, a similar difference existed $(\mathrm{P}<0.01)$. However, the percentage of thyroxine bound to TBP in neonatal sera was significantly less than that bound to TBP in maternal sera, except at the lowest concentration of added thyroxine employed.

The concentrations of total protein in the neonatal sera $(6.1 \pm 0.5 \mathrm{gm}$. per cent) were not significantly different from the values in the maternal sera $(6.2 \pm 0.3 \mathrm{gm}$. per cent), nor were the concentrations of albumin in neonatal sera $(3.4 \pm 0.2$ gm. per cent) significantly greater than those values in maternal sera $(3.3 \pm 0.3 \mathrm{gm}$. per cent $)$. Concentrations of total protein and albumin in maternal and neonatal sera were significantly less than control values $(\mathrm{P}<0.01)$. Differences in the composition of sera from non-pregnant women, from pregnant women at term, and from neonatal infants are represented in the densitometric scans depicted in Figure 5.

Table VII depicts one of four experiments in
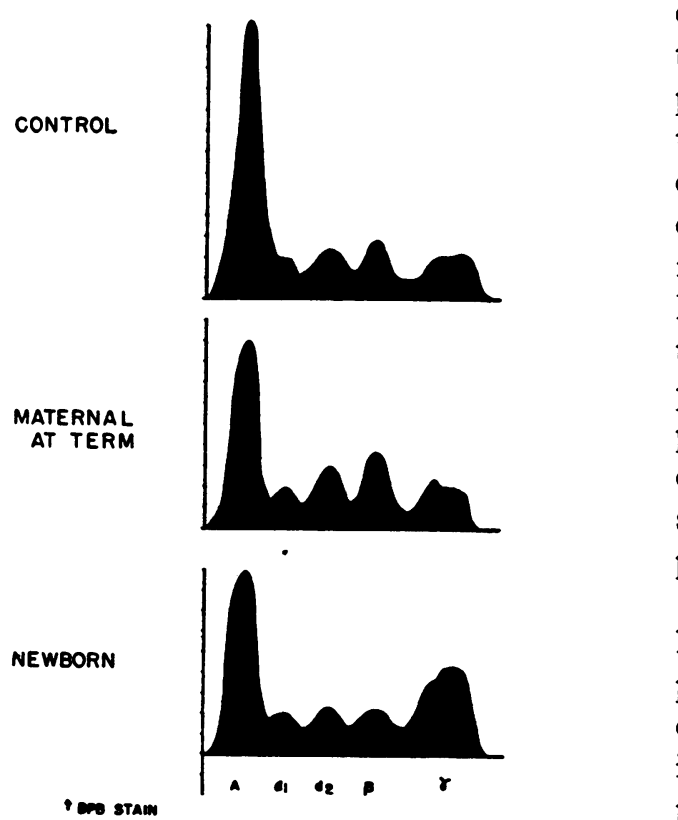

Fig. 5. Photoelectric Densitometry Applied to Electrophoretograms, Stained with Brom-phenol. Blue, of Control, Maternal, and Neonatal Sera

Sera were electrophoresed in Whatman 3 filter-paper at $\mathrm{pH} 8.6$, barbital buffer, ionic strength 0.05 for 16 hours at 120 volts. Curves represent average values of optical density from densitometry applied to all electrophoretograms of the experiment comparing the sera described. which sera were diluted tenfold and then supplemented with sufficient albumin and radiothyroxine to simulate the concentrations of total protein and PBI which are reportedly present in extracellular fluid (27). In all of these studies, an enhanced TBP-activity was exhibited by artificial "extracellular fluid" mixtures prepared from sera of normally pregnant women.

\section{DISCUSSION}

When thyroxine is added to plasma, it partitions among the plasma proteins according to their relative binding affinities for this hormone. At physiological concentrations, thyroxine in plasma is principally associated with a protein (or proteins) which, at $\mathrm{pH} 8.6$, displays an electrophoretic mobility intermediate to that of the alpha- 1 and alpha-2 globulins (7-11). This globulin moiety has been designated the thyroxine-binding protein of plasma (TBP). As the concentration of thyroxine in plasma is increased, a progressively larger fraction of the hormone is bound to albumin, its chief secondary carrier $(26,28,29,24)$.

In the present communication, it has been demonstrated that similar qualitative relationships obtain in maternal serum during electrophoresis at $\mathrm{pH} 8.6$ and $\mathrm{pH}$ 4.5. Measurement of the partition of thyroxine, in several standardized concentrations, between TBP and albumin affords a convenient means for intercomparing the thyroxine-binding activity of TBP in individual sera. By means of this technique, a marked augmentation has been found in the thyroxine-binding capacity of TBP in sera obtained from normally pregnant women. This augmentation begins as early as the twenty-first postovulatory day, persists throughout pregnancy, and into the puerperium.

In confirmation of earlier reports, moderate hypoalbuminemia has been found in normally pregnant women (14-16). Since the distribution of thyroxine between albumin and TBP in vitro is in part dependent on the concentration of these proteins, it seemed possible that either physiological hypoalbuminemia or some alteration in the binding properties of maternal albumin might explain the unusual avidity for thyroxine of TBP in maternal sera. This did not prove to be the case. Correction of hypoalbuminemia by the in vitro addition of an albumin which exhibited considerable thyroxine-binding potency, and which had been 
obtained from multiple non-pregnant donors, did not demonstrably alter the distribution of thyroxine among the proteins of maternal sera.

The above observations concern the partition of thyroxine among the proteins of plasma under circumstances in which the total concentration of thyroxine has been increased approximately 100 per cent during the addition of radioactive hormone. At truly physiological concentrations of thyroxine, so small a fraction of radiothyroxine is bound to albumin that assessment of a possible increase in TBP-activity of maternal sera is technically unfeasible. However, when truly tracer amounts of radiothyroxine were employed, and sera were diluted and supplemented with albumin so that concentrations both of total protein and of PBI approached those reportedly present in extracellular fluid (27), enhancement of TBPactivity in maternal sera as compared to controls could once again be demonstrated.

Since direct measurement of the concentration of TBP in serum cannot yet be made, it is not possible to ascertain whether the present findings result from an absolute increase at the quantity of TBP in the serum of pregnant women or from an alteration in those molecular characteristics of TBP which determine its affinity for thyroxine.

Although the enhanced TBP activity in sera from pregnant patients is as yet unexplained, several observations suggest that hormonal changes occurring during pregnancy may be implicated. The initial appearance and the subsequent post-partum disappearance of augmentations both in SPI and in binding capacity of TBP are temporally well correlated. Secondly, Engstrom, Markardt, and Liebman have demonstrated that large doses of estrogen are capable of inducing augmentation of the SPI in males and non-pregnant females $(30,31)$. Finally, early and continued increase in the elaboration of estrogens occurs during the pregnant state (32). For these reasons, diethylstilbestrol, in doses of $30 \mathrm{mg}$. daily, has been administered to a group of non-pregnant females. Preliminary data indicate that this regimen induces, within 4 weeks, an increase in the thyroxine-binding capacity of TBP similar to that seen during pregnancy. It would thus appear that increased elaboration of estrogen during pregnancy may be at least in part responsible for the phenomena reported above. However, the extent to which other hormonal or non-hormonal factors may be contributory remains to be determined.

In this regard it is perhaps noteworthy that among 6 patients with spontaneous abortion, 4 failed to demonstrate alterations in TBP of the magnitude observed in normal pregnancy. In 2 patients with threatened abortion, augmentations of thyroxine-binding by TBP similar to those seen during normal pregnancy were found. One of these patients is in her ninth month of apparently normal pregnancy, and the other recently underwent normal parturition. It is unlikely that failure to demonstrate the usual gravid change in thyroxine-binding can be explained by recent death of the fetus, since following normal pregnancy increased thyroxine-binding is evident for as long as 5 weeks post partum. In the abnormal situation, it appears more likely that the usual gravid changes had either failed to appear or that the stimuli responsible for their production had been withdrawn a considerable period before actual abortion. Whether this sequence reflects inadequacies of implantation and trophoblastic function originating in the conceptus, or inadequacies in the maternal response to normal pregnancy remains undetermined.

Whether thyroxine crosses the placental barrier in humans is unknown. In confirmation of earlier reports $(13,33)$, SPI's in maternal and cord blood, although not identical, were not, in the present study, significantly different. A free passage of all proteins between maternal and fetal circulations is unlikely, since with the exception of gamma globulin, the electrophoretic components of serum obtained from cord blood resemble those of the non-pregnant adult more nearly than those of the mother (34). Nevertheless, it has been demonstrated that various gamma globulins pass from the maternal to the fetal circulation (35). In the present study, the thyroxine-binding capacity of TBP in neonatal serum has been shown to exceed that of the non-pregnant adult. It is unknown at present whether this reflects transplacental passage of TBP, a fetal response conditioned by those factors which induce alterations of maternal TBP, or an innate characteristic of the newborn.

The physiological role of the thyroxine-binding protein is unknown. It is not possible, therefore, to evaluate with certainty the relation of the increased binding capacity of TBP to the other al- 
terations in the metabolism of iodine which occur during pregnancy. However, certain observations concerning the effects of TBP on the metabolism of thyroxine by tissue slices afford a basis for a preliminary hypothesis. Older observations of increase during pregnancy in number and size of thyroidal follicles, hyperplasia of follicular epithelium, and increased vascularity provide anatomical evidence of thyroidal hyperfunction. Recently, Ferraris and Scorta, studying 22 pregnant women, found an augmentation in thyroidal accumulation of $I^{131}$ appearing in the first trimester, persisting throughout pregnancy, and returning to normal by the thirtieth post-partum day. Twenty-four-hour plasma $\mathrm{I}^{131}$ conversion ratios were also increased (3). Earlier, Pochin had described augmented accumulation of radioiodine in 5 pregnant women (2). These data indicate that unless dietary iodine is diminished, there occur during pregnancy increased glandular production and release of iodinated materials. Furthermore, evidence obtained by butanol-extraction and chromatographic techniques indicates that thyroxine is the principal iodinated compound contributing to the augmented SPI of pregnancy $(3,12,13)$. Thus, there is evidence during pregnancy of the thyroidal production and release of increased quantities of calorigenically potent hormone.

However, in spite of this increase in the production and circulating concentration of thyroid hormone, there is no associated augmentation of basal energy requirements beyond those which may be attributable to the needs of the fetus. Pregnancy thus appears to disrupt the usual relationship between augmented concentration of circulating thyroid hormone and cellular metabolic response. Further evidence of a dissociation of this nature is provided by the amelioration of thyrotoxicosis and reduction in requirement for antithyroid drug, often observed in thyrotoxic pregnant patients (36-38). Humoral factors during pregnancy might reduce metabolic responsiveness of tissues to thyroid hormone or directly reduce respiration in tissues (39). However, this possibility is rendered unlikely by the observation that ameliorated thyrotoxicosis may not exacerbate until 9 or 10 weeks post partum (40), long after evidence of increased secretion of at least estrogenic and adrenocortical hormones has disappeared $(32,41)$. Furthermore, in normal women, hyperthyroidism does not appear during that portion of the puerperium in which estrogenic alterations have regressed and SPI remains increased.

If tissue responsivity is indeed undiminished, then the majority of maternal tissues must receive at most a normal quantity of hormone, despite the increase in SPI. There is at present no direct evidence that TBP participates in producing this alteration in proportional cellular penetration. Nevertheless, data obtained in an in vitro system suggest that it may. In vitro, the static distribution of thyroxine between extracellular and cellular phases is conditioned by the relative abundance of extracellular and cellular thyroxinebinding components (42). Thus, in pregnancy, enhanced extracellular TBP could provide for the passage of only normal quantities of thyroxine to most maternal tissues, and could, in this way, protect them from the usual metabolic effects of increased concentration of circulating thyroid hormone. Increased amounts of thyroxine might be directed to particular maternal tissues, such as uterus, placenta, or perhaps fetus, whose requirements for hormone may be augmented, or alternatively might be channeled to sites in which hormonal degradation is not linked to metabolic action. This could be accomplished if the binding potential of these tissues favored the ready passage of thyroxine from TBP to cellular binding sites.

However, findings in the static system need not reflect the role of TBP in the dynamically equilibrated living system. In vivo, thyroxine may enter the cell in association with TBP. If this were true, delivery of thyroxine to tissues would be limited by the transcellular flux or cellular degradation of TBP. If, then, during pregnancy, thyroxine and TBP are increased proportionately, so that their molecular ratio remains constant, continued passage of normal amounts of TBP into the majority of maternal tissues would provide for the cellular penetration of normal quantities of thyroxine. Furthermore, the needs of certain tissues with increased hormonal requirements, such as those noted above, could be met by the intracellular passage of increased amounts of TBP. Under either of these circumstances, overall fractional rate of turnover of thyroxine dur- 
ing pregnancy might increase, decrease, or might, as suggested by the data of Danowski, Schwartz, Rhodes, Yoder, Puntereri, and Mateer, remain normal (43).

It is apparent that the foregoing correlations are largely conjectural, being based on the limited data available, and omitting from consideration such variables as the number and avidity for thyroxine of cellular binding sites. Nevertheless, they appear to afford, at least, a conceptual frame of reference for future investigation of those puzzling alterations of thyroidal economy which occur during pregnancy.

\section{SUMMARY}

The partition of thyroxine between albumin and the specific thyroxine-binding protein (TBP) has been compared in sera obtained from non-pregnant and pregnant women. At all concentrations of thyroxine studied, a greater percentage was bound to TBP in sera of normally pregnant women than in sera of controls. Data obtained from supplementation of maternal sera with mercaptalbumin suggest that the observed alteration in thyroxine-binding does not result from the physiological hypoalbuminemia of pregnancy. Alteration in thyroxine-binding begins early in pregnancy and persists well into the puerperium. A similar though less marked augmentation of thyroxine-binding by TBP has been noted in sera obtained from umbilical cord bloods. Several patients with a diagnosis of threatened or inevitable abortion failed to demonstrate a change in thyroxine-binding capacity of TBP of the magnitude seen in normal pregnancy of similar duration.

\section{ACKNOWLEDGMENTS}

The authors are indebted to Dr. Benjamin Tenney, Chief, Obstetrical and Gynecological Service, Boston City Hospital, for providing the opportunity to obtain sera from pregnant patients.

The technical assistance of Miss Nancy Warr, Miss Kathryn Tomikawa, and Miss Alice Ballou is gratefully acknowledged.

\section{REFERENCES}

1. Eastman, N. J., in Williams, J. W., Obstetrics. 10 th ed. New York, Appleton-Century-Crofts, Inc., 1950.

2. Pochin, E. E., The iodine uptake of the human thyroid throughout the menstrual cycle and in pregnancy. Clin. Sc., 1952, 11, 441.
3. Ferraris, G. M., and Scorta, A., Comportamento di alcuni tests di funzione tiroidea in gravidanza $e$ in puerperio. Minerva Gin., 1955, 7, 308.

4. Heinemann, M., Johnson, C. E., and Man, E. B., The serum-precipitable iodine concentrations during pregnancy. J. Clin. Invest., 1948, $27,91$.

5. Russell, K. P., The current status of the proteinbound blood iodine in obstetrics and gynecology. Obst. \& Gynec. Surv., 1954, 9, 157.

6. Sandiford, I., and Wheeler, T., The basal metabolism before, during, and after pregnancy. J. Biol. Chem., 1924, 62, 329.

7. Gordon, A. H., Gross, J., O'Connor, D., and PittRivers, R., Nature of the circulating thyroid hormone-plasma protein complex. Nature, 1952, 169, 19.

8. Larson, F., Deiss, W. P., and Albright, E. C., Localization of protein-bound radioactive iodine by filter paper electrophoresis. Science, 1952, 115, 626.

9. Robbins, J., and Rall, J. E., Zone electrophoresis in filter paper of serum $I^{2 m}$ after radioiodide administration. Proc. Soc. Exper. Biol. \& Med., 1952, 81, 530.

10. Winzler, R. J., and Notrica, S. R., Association of thyroxine with plasma proteins. Federation Proc., 1952, 11, 312.

11. Horst, W., and Rösler, H., Der Transport des Hormonjods im menschlichen Serum untersucht mit Papierelektrophorese und Radiojod. (Zugleich ein Beitrag zur Frage der Existenz von sog. Zwischenfraktionen.) Klin. Wchnschr., 1953, 31, 13.

12. Danowski, T. S., Gow, R. C., Mateer, F. M., Everhart, W. C., Johnston, S. Y., and Greenman, J. H., Increases in serum thyroxine during uncomplicated pregnancy. Proc. Soc. Exper. Biol. \& Med., 1950, 74, 323.

13. Man, E. B., Pickering, D. E., Walker, J., and Cooke, R. E., Butanol-extractable iodine in the serum of infants. Pediatrics, 1952, 9, 32.

14. Longsworth, L. G., Curtis, R. M., and Pembroke, R. H., Jr., The electrophoretic analysis of maternal and fetal plasmas and sera. J. Clin. Invest., 1945, 24, 46.

15. Coryell, M. N., Beach, E. F., Robinson, A. R., Macy, I. G., and Mack, H. C., Metabolism of women during the reproductive cycle. XVII. Changes in electrophoretic patterns of plasma proteins throughout the cycle and following delivery. J. Clin. Invest., 1950, 29, 1559.

16. Brown, T., Electrophoretic analysis of serum proteins in pregnancy; a preliminary study. J. Obst. \& Gynaec. Brit. Emp., 1954, 61, 781.

17. Dowling, J. T., Freinkel, N., and Ingbar, S. H., Thyroxine-binding by sera of pregnant women. J. Clin. Endocrinol. \& Metab., 1956, 16, 280.

18. Rutstein, D. D., Ingenito, E. F., and Reynolds, W. E., The determination of albumin in human blood plasma and serum. A method based on the interaction of albumin with an anionic dye-2-(4'-hy- 
droxybenzeneazo) benzoic acid. J. Clin. Invest., 1954, 33, 211.

19. Cohn, E. J., Strong, L. E., Hughes, W. L., Jr., Mulford, D. J., Ashworth, J. N., Melin, M., and Taylor, H. L., Preparation and properties of serum and plasma proteins. IV. A system for the separation into fractions of the protein and lipoprotein components of biological tissues and fluids. J. Am. Chem. Soc., 1946, 68, 459.

20. Hughes, W. L., Jr., An albumin fraction isolated from human plasma as a crystalline mercuric salt. J. Am. Chem. Soc., 1947, 69, 1836.

21. Mehl, J. W., The biuret reaction of proteins in the presence of ethylene glycol. J. Biol. Chem., 1945, 157, 173.

22. Barker, S. B., Determination of protein-bound iodine. J. Biol. Chem., 1948, 173, 715.

23. Barker, S. B., Humphrey, M. J., and Soley, M. H., The clinical determination of protein-bound iodine. J. Clin. Invest., 1951, 30, 55.

24. Freinkel, N., Dowling, J. T., and Ingbar, S. H., The interaction of thyroxine with plasma proteins: localization of thyroxine-binding in Cohn fractions of plasma. J. Clin. Invest., 1955, 34, 1698.

25. Durrum, E. L., A microelectrophoretic and microionophoretic technique. J. Am. Chem. Soc., 1950, 72, 2943.

26. Albright, E. C., Larson, F. C., and Deiss, W. P., Thyroxine binding capacity of serum alpha globulin in hypothyroid, euthyroid, and hyperthyroid subjects. J. Clin. Invest., 1955, 34, 44.

27. Salter, W. T., The metabolic circuit of the thyroid hormone. Ann. New York Acad. Sc., 1949, 50, 358.

28. Deiss, W. P., Albright, E. C., and Larson, F. C., A study of the nature of the circulating thyroid hormone in euthyroid and hyperthyroid subjects by use of paper electrophoresis. J. Clin. Invest., 1952, 31, 1000.

29. Robbins, J., and Rall, J. E., Thyroxine-binding capacity of serum in normal man. J. Clin. Invest., 1955, 34, 1324.
30. Engstrom, W. W., Markardt, B., and Liebman, A., Effect of estrogens on serum precipitable iodine. Proc. Soc. Exper. Biol. \& Med., 1952, 81, 582.

31. Engstrom, W. W., and Markardt, B., Influence of estrogen on thyroid function. J. Clin. Endocrinol. \& Metab., 1954, 14, 215.

32. Sunderman, F. W., and Boerner, F., Normal Values in Clinical Medicine. Philadelphia \& London, W. B. Saunders Company, 1949.

33. Danowski, T. S., Johnston, S. Y., Price, W. C., McKelvy, M., Stevenson, S. S., and McCluskey, E. R., Protein-bound iodine in infants from birth to one year of age. Pediatrics, 1951, 7, 240.

34. Russ, E. M., Eder, H. A., and Barr, D. P., Protein-lipid relationships in human plasma. III. In pregnancy and the newborn. J. Clin. Invest., 1954, 33, 1662.

35. Kuhns, W. J., Types and distribution of antibodies. Am. J. Med., 1956, 20, 251.

36. Javert, C. T., Hyperthyroidism and pregnancy. Am. J. Obst. \& Gynec., 1940, 39, 954.

37. Engstrom, W. W., Kydd, D. M., Peters, J. P., and Man, E. B., The precipitable iodine of serum in pregnancy complicated by disorders of the thyroid. J. Clin. Invest., 1951, 30, 151.

38. Astwood, E. B., The use of antithyroid drugs during pregnancy. J. Clin. Endocrinol., 1951, 11, 1045.

39. Guidry, M. A., Segaloff, A., and Altschul, A. M., The effect of a-estradiol, some of its esters and estrone on the respiration of tissue homogenates. Endocrinology, 1952, 50, 29.

40. Man, E. B., Personal communication.

41. Venning, E. H., Adrenal function in pregnancy. Endocrinology, 1946, 39, 203.

42. Freinkel, N., Ingbar, S. H., and Dowling, J. T., The influence of extracellular thyroxine binding protein upon the accumulation of thyroxine by tissue slices. J. Clin. Invest., 1957, 36, No. 1.

43. Danowski, T. S., Schwartz, R., Rhodes, G. J., Yoder, R. D., Puntereri, A. J., and Mateer, F. M., Serum protein-bound iodine levels following administration of thyroxine in various diseases. J. Clin. Endocrinol. \& Metab., 1955, 15, 1116. 